\title{
THE EFFECT OF EMOTIONAL INTELLIGENCE, HUMAN RELATION AND LEADERSHIP STYLES ON EMPLOYEE PERFORMANCE AT THE LOKA REHABILITATION BNN BATAM
}

\author{
Meta Amelia Widya Saputri ${ }^{1}$, Ngaliman ${ }^{2}$, Indrayani ${ }^{3}$, Muammar Khaddafi ${ }^{4}$ \\ 1,2,3 Magister Manajemen, Universitas Batam \\ ${ }^{4}$ Fakultas Ekonomi, Universitas Malikussaleh Lhokseumawe \\ Correspondence Address: Jl. Abdulyatama No 5, Batam, Kepulauan Riau. \\ E-mail: ${ }^{1)}$ meta.amelia88@gmail.com
}

\begin{abstract}
The purpose of this study was to determine and analyze the effect of emotional intelligence, human relations and leadership style on employee performance in Loka Rehabilitasi BNN Batam. The research method used in this research is quantitative method. The population in this study were all employees at the agency totaling 90 people, with a sample size of 74 people. The data used in this study are primary data, namely by using a questionnaire made with a Likert scale. Data analysis techniques are quantitative data analysis techniques using statistical methods. Based on the results of data analysis, it was found that emotional intelligence had a positive and significant effect on employee performance variables, human relations had a positive and significant effect on employee performance variables, leadership style had a positive and significant effect on employee performance variables.
\end{abstract}

Keywords: Emotional Intelligence, Human Relation, Leadership style, employee performance.

\section{INTRODUCTION}

Loka Rehabilitasi BNN Batam is a government-owned rehabilitation site that was inaugurated since 2014. The BNN Rehabilitation Workshop employees consist of Civil Servants and Non-Civil Servant Government Employees (PPNPN) or commonly known as contract workers, where both play a role as human resources which are the main assets. within the agency. Sudarsono (2006, p. 67) states that human resources are potential and cannot be separated from organizations or work units. For this reason, it is necessary to ensure that the human resources owned by each agency have good performance so that the goals or targets of these agencies can be achieved.

According to Rivai and Basri (2005) performance is the willingness of a person or group of people to carry out an activity and perfect it according to their responsibilities with the expected results. According to Bambang Guritno and Waridin (2005), performance is a comparison of the work achieved by employees with predetermined standards. Meanwhile, according to Hakim (2006) defines performance as a result of work achieved by an individual that is adjusted to the role or task of the individual in a company in a certain period of time, which is associated with a certain value or standard measure of the company where the individual works.

Humans as the main asset in an institution have several types of intelligence, one of which is emotional intelligence. According to Dyanisa (2008), emotional intelligence is the ability and potential in an individual to be able to recognize, understand, manage and lead one's own feelings, so that the individual can empathize with others and respect others, and apply or apply it in dealing with emotional impulses in everyday life. According to Goleman (2015) emotional intelligence is the ability of a person to manage his emotional life with intelligence; maintaining emotional harmony and expressing it through self-awareness, self-control, self-motivation, empathy and social skills. With good emotional intelligence, it is hoped that employees can give good performance wherever they work. 
Another factor that may affect performance is human relations. Humans as social creatures need interaction in their daily lives, both in the environment where they live and in the work environment. According to Davis (1989: 152), Human Relations is a relationship or interaction between a person and another person in either a work situation or in an organization. According to Onong (2001: 138), Human Relations is a human relationship, not a human relationship, it's just that Human Relations here is not like ordinary communicators, not only the delivery of a message by someone to another, but the relationship between people. that communicating contains very deep psychological elements. With the existence of good human relations between interested parties in an agency, it is hoped that it can improve employee performance.

Like any government agency, the leader or head will change over time. Each leader has a leadership style that may vary. Leadership is the ability to influence people to achieve organizational goals (Daft, 2006: 313), further Rifai (2006: 2) argues that leadership broadly includes the process of influencing in determining organizational goals, motivating follower behavior to achieve goals, and influencing to improve the group and its culture. According to another opinion put forward by Hasibuan (2005: 170) defines leadership as a way for a leader to influence the behavior of his subordinates so that they are willing to cooperate and work productively to achieve organizational goals. In carrying out their duties, each leader has their own leadership style. Based on the opinions above, leadership style can affect employee performance.

Based on the background that has been described, the researchers are interested in conducting a study entitled The Effect of Emotional Intelligence, Human Relations and Leadership Style on Employee Performance. This research was conducted in the institution where the researcher works, thus the researcher hopes that the results of this study can be used as input to the Human Resources division in recruiting, input for employees in human relations and also input for the head of an agency in carrying out a leadership style in order to achieve organizational goals.

\section{IMPLEMENTATION METHOD}

The type of data collected in this study is quantitative data. Quantitative data is a type of data that can be measured or calculated directly, in the form of information both orally and in writing, which acts as data to be measured in this discussion. Sources of data collected in this study are primary data, namely data obtained directly from the object of research. The data method used in this study is a questionnaire, which is an interview between the researcher and the respondent or other party related to useful information on the problem or proof of the hypothesis that has been put forward to obtain a research. The second method is observation, by observing the activity of the object of research for accurate information about the circumstances associated with this research. The last is literature, which is conducting literature research to obtain information and theories that have developed in research. While the data tool used was a questionnaire which was tested using SPSS version 25 . The answers to each instrument using the Likert scale have a gradient from very positive to very negative with the following categories:

Tabel 1.1

Likert Scale

\begin{tabular}{|c|c|}
\hline Keterangan & Skala \\
\hline Strongly agree & $\mathbf{5}$ \\
\hline Agree & $\mathbf{4}$ \\
\hline Doubtful & $\mathbf{3}$ \\
\hline
\end{tabular}




\begin{tabular}{|c|c|}
\hline Disagree & $\mathbf{2}$ \\
\hline Strongly Disagree & $\mathbf{1}$ \\
\hline
\end{tabular}

This study uses a quantitative method, where data collection is carried out using probability sampling techniques, which means that each object has an equal chance of being selected as a sample member. Determination of the number of samples using the Slovin formula, with a significance level of error tolerance of 5\%, so that the number of respondents was 74 people from a total population of 90 employees.

\section{RESULTS AND DISCUSSION}

The validity test is carried out to determine the extent of the determination and reflection of the questions of the research tool in carrying out its function. The validity test is intended to see the consistency of the independent variable with what is being measured, in addition to knowing how far the measuring instrument is and can provide a picture of the object to be studied. The program used to test the validity and the SPSS (Statistical Program For Social Science) computer program. This validity test is based on the $r$ table formula and the level of significance in this table is $0.05 \%$ or $5 \%$ with a sample size of 74 respondents.

From the results of the validity for the 5 question items, it was found that all items had a correlation probability score of $r<0.05$ ( $\mathrm{r}_{\text {table }}<\mathrm{r}_{\text {count }}$ ) meaning valid and if on the other hand $>0.05$ it meant invalid. Instruments for Emotional Intelligence (X1), Human Relations (X2), Leadership Style (X3) and Employee Performance (Y) fulfill the validity test of this provision based on the basic SPSS guidelines for decision making, namely:

1. If $r_{\text {count }}>r_{\text {table }}$ means valid

2. If $\mathrm{r}_{\text {count }}<\mathrm{r}_{\text {tabel }}$ means invalid

3. $r_{\text {tabel }}=$ for $\alpha=0.05$ and degrees of freedom $(\mathrm{df}=\mathrm{n}-2) \mathrm{r}_{\text {table }}=0.228$

Tabel 1.2

Validity Test Results for each variable

\begin{tabular}{|c|l|l|l|l|l|}
\hline Variabel & Item & r Count & r Tabel & Sig & information \\
\hline \multirow{2}{*}{$\begin{array}{c}\text { Emotional } \\
\text { Intelligence (X1) }\end{array}$} & $\mathrm{X} 1.1$ & 0,815 & 0,2287 & 0,000 & Valid \\
\cline { 2 - 6 } & $\mathrm{X} 1.2$ & 0,861 & 0,2287 & 0,000 & Valid \\
\cline { 2 - 6 } & $\mathrm{X} 1.3$ & 0,785 & 0,2287 & 0,000 & Valid \\
\cline { 2 - 6 } & $\mathrm{X} 1.4$ & 0.778 & 0,2287 & 0,000 & Valid \\
\cline { 2 - 6 } & $\mathrm{X} 1.5$ & 0,754 & 0,2287 & 0,000 & Valid \\
\hline \multirow{4}{*}{$\begin{array}{c}\text { Human Relation } \\
\text { (X2) }\end{array}$} & $\mathrm{X} 1.1$ & 0,685 & 0,2287 & 0,000 & Valid \\
\cline { 2 - 6 } & $\mathrm{X} 1.2$ & 0,804 & 0,2287 & 0,000 & Valid \\
\cline { 2 - 6 } & $\mathrm{X} 1.3$ & 0,853 & 0,2287 & 0,000 & Valid \\
\cline { 2 - 6 } & $\mathrm{X} 1.4$ & 0.778 & 0,2287 & 0,000 & Valid \\
\cline { 2 - 6 } & $\mathrm{X} 1.5$ & 0,751 & 0,2287 & 0,000 & Valid \\
\hline \multirow{5}{*}{$\begin{array}{c}\text { Leadership } \\
\text { Styles (X3) }\end{array}$} & $\mathrm{X} 3.1$ & 0,823 & 0,2287 & 0,000 & Valid \\
\cline { 2 - 6 } & $\mathrm{X} 3.2$ & 0,881 & 0,2287 & 0,000 & Valid \\
\cline { 2 - 6 } & $\mathrm{X} 3.3$ & 0,793 & 0,2287 & 0,000 & Valid \\
\cline { 2 - 6 } & $\mathrm{X} 3.4$ & 0,822 & 0,2287 & 0,000 & Valid \\
\cline { 2 - 6 } & $\mathrm{X} 3.5$ & 0,812 & 0,2287 & 0,000 & Valid \\
\hline
\end{tabular}

International Journal of Social Science, Educational, Economics, Agriculture Research, and Technology (IJSET) 
THE EFFECT OF EMOTIONAL INTELLIGENCE, HUMAN RELATION AND LEADERSHIP STYLES ON EMPLOYEE PERFORMANCE AT THE LOKA REHABILITATION BNN BATAM DOI: https://doi.org/10.54443/ijset.v1i2.10

\begin{tabular}{|c|l|l|l|l|l|}
\hline \multirow{4}{*}{$\begin{array}{c}\text { Employee } \\
\text { Performance (Y) }\end{array}$} & Y.1 & 0,828 & 0,2287 & 0,000 & Valid \\
\cline { 2 - 6 } & Y.2 & 0,864 & 0,2287 & 0,000 & Valid \\
\cline { 2 - 6 } & Y.3 & 0,816 & 0,2287 & 0,000 & Valid \\
\cline { 2 - 6 } & Y.4 & 0,820 & 0,2287 & 0,000 & Valid \\
\cline { 2 - 6 } & Y.5 & 0,856 & 0,2287 & 0,000 & Valid \\
\hline
\end{tabular}

The results of the validity test above as shown in table 1.2 show that all questions have a value of $r$ count $>r$ table, with a significant level of $\alpha=0.05$ and a value of $r$ table of 0.2287 , it can be concluded that all statements on variables $\mathrm{X} 1, \mathrm{X} 2, \mathrm{X} 3$ and $\mathrm{Y}$ is declared valid. Reliability testing is carried out to determine the extent to which a measuring instrument can be trusted or not. SPSS provides a test facility to measure reliability with the Cronbach Alpha $(\alpha)$ statistical test. A variable can be said to be reliable if it gives $\alpha>$ 0.60 (Ghozali, 2009: 89). The basis for making decisions, namely:

1. If the reliability value $>0.60$ then the statement is reliable.

2. If the reliability value $<0.060$ then the statement is not reliable.

Furthermore, valid instrument items in table 4.6 were tested using Cronbach Alpha for reliability testing. It can be seen from the following table :

Tabel 1.3

Reliability Test Resul

\begin{tabular}{|l|c|c|l|}
\hline \multicolumn{1}{|c|}{ Variabel } & $\begin{array}{c}\text { Cronbach's } \\
\text { Alpha }\end{array}$ & $\begin{array}{c}\text { Parameter } \\
\text { Reliability }\end{array}$ & information \\
\hline Emotional Intelligence (X1) & 0,858 & 0.060 & Reliabel \\
\hline Human Relation (X2) & 0,833 & 0.060 & Reliabel \\
\hline Leadership Style (X3) & 0,882 & 0.060 & Reliabel \\
\hline Employee Performance (Y) & 0,892 & 0.060 & Reliabel \\
\hline \multicolumn{1}{|c|}{ Variabel } & $\begin{array}{c}\text { Cronbach's } \\
\text { Alpha }\end{array}$ & $\begin{array}{c}\text { Parameter } \\
\text { Reliability }\end{array}$ & information \\
\hline Emotional Intelligence (X1) & 0,858 & 0.060 & Reliabel \\
\hline Human Relation (X2) & 0,833 & 0.060 & Reliabel \\
\hline Leadership Style (X3) & 0,882 & 0.060 & Reliabel \\
\hline Employee Performance (Y) & 0,892 & 0.060 & Reliabel \\
\hline \multicolumn{1}{|c|}{ Variabel } & Cronbach's & Parameter & information \\
Alpha & Reliability & \\
\hline Emotional Intelligence (X1) & 0,858 & 0.060 & Reliabel \\
\hline Human Relation (X2) & 0,833 & 0.060 & Reliabel \\
\hline Leadership Style (X3) & 0,882 & 0.060 & Reliabel \\
\hline Employee Performance (Y) & 0,892 & 0.060 & Reliabel \\
\hline
\end{tabular}

From the table above, it can be seen that the R Alpha of each of the X1, X2, X3 and $\mathrm{Y}$ variables is greater than 0.60 . Thus it can be concluded that the data being tested is declared reliable. 
Analysis of the Effect of Emotional Intelligence (X1) on Employee Performance (Y) To determine the effect of Emotional Intelligence (X1) on the Employee Performance variable (Y), several tests and guidelines must be carried out to provide coefficient interpretation. According to Sugiyono (2010: 250) the correlation is as follows:

Tabel 1.4

Guidelines for Providing Interpretation of Correlation Coefficients

\begin{tabular}{|c|c|}
\hline Interpretation R Value & Interpretation \\
\hline$, 00-0,199$ & Sangat Rendah \\
\hline $0,20-0,399$ & Rendah \\
\hline $0,40-0,599$ & Sedang \\
\hline $0,60-0,799$ & Kuat \\
\hline $0,80-0.999$ & Sangat Kuat \\
\hline
\end{tabular}

Source : Sugiyono (2010:250)

Tabel 1.5

Results of the Determination of Emotional Intelligence

Model Summary

\begin{tabular}{|l|c|r|r|r|}
\hline Model & $\mathrm{R}$ & R Square & \multicolumn{1}{c|}{$\begin{array}{c}\text { Adjusted R } \\
\text { Square }\end{array}$} & $\begin{array}{c}\text { Std. Error of } \\
\text { the Estimate }\end{array}$ \\
\hline 1 &, $653^{\mathrm{a}}$ &, 427 &, 415 & 1,91817 \\
\hline
\end{tabular}

a. Predictors: (Constant), KECERDASAN EMOSIONAL

b. Dependent Variable: KINERJA PEGAWAI

\section{Source: Results of SPSS 25 data processing}

Based on the results of the output above, it can explain the summary of the model, which consists of the results of the simple correlation value $\mathrm{R}$ and the coefficient of determination ( $\mathrm{R}$ Square).

1. $\mathrm{R}$ (Pearson correlation) the resulting value is 0.653 , which means that the variable Emotional Intelligence (X1) and employee performance (Y) has a moderate level of relationship.

2. $\mathrm{R}$ square of 0.427 means that the percentage share of the influence of the Emotional Intelligence variable (X1) with the employee performance variable $(\mathrm{Y})$ is 0.427 . This means that the percentage level of the influence of Emotional Intelligence (X) with the employee performance variable (Y) is $42.7 \%$ and the rest is influenced by other variables not examined in this study.

Simple linear regression is used to determine the effect of two or more independent variables with one dependent variable. Following are the results of a simple linear regression test.

Tabel 1.6

Emotional Intelligence Simple Linear Regression Test Results

Coefficients $^{a}$

\begin{tabular}{|c|c|c|c|c|c|c|}
\hline \multirow{2}{*}{\multicolumn{2}{|c|}{ Model }} & \multicolumn{2}{|c|}{ Unstandardized Coefficients } & \multirow{2}{*}{$\begin{array}{c}\begin{array}{c}\text { Standardized } \\
\text { Coefficients }\end{array} \\
\text { Beta }\end{array}$} & \multirow[b]{2}{*}{$t$} & \multirow[b]{2}{*}{ Sig. } \\
\hline & & B & Std. Error & & & \\
\hline \multirow[t]{2}{*}{1} & (Constant) & 6,982 & 2,430 & & 2,874 &, 006 \\
\hline & $\begin{array}{l}\text { KECERDASAN } \\
\text { EMOSIONAL }\end{array}$ &, 677 &, 113 &, 653 & 5,980 &, 000 \\
\hline
\end{tabular}

a. Dependent Variable: KINERJA PEGAWAI 


$$
\mathrm{Y}=\mathrm{a}+\mathrm{bX1}=\mathbf{6 , 9 8 2}+\mathbf{0 , 6 7 7}
$$

Nilai persamaan regresi diatas dapat dijelaskan sebagai berikut :

1. The constant value (a) is 6.982, meaning that if the Emotional Intelligence variable (X1) is 0 , the employee performance variable $(\mathrm{Y})$ gets 6.982 .

2. The regression coefficient value of the Emotional Intelligence variable (X1) is 0.677, which means that if the other independent variables are fixed and the Emotional Intelligence (X1) increases by $1 \%$, then the employee's performance (Y) will increase by $67.7 \%$. The coefficient is positive, meaning that there is a positive relationship between the work environment and employee performance, the better the level of the work environment, the higher the employee's performance.

The $t$ test is used to test each variable whether it has a significant relationship between the independent variable and the dependent variable. How to determine which variables have a significant relationship are as follows:

1. If tcount $>$ ttable at $\alpha=0.05$ then Ho is rejected or Ha is accepted.

2. If tcount $>$ ttable at $\alpha=0.05$ then Ho is accepted and Ha is rejected.

3. The $t$ distribution table is sought at $\alpha=0.05$ with degrees of freedom (df) $n-k$ or $74-2=72$ ( $\mathrm{n}$ is the number of cases, and $\mathrm{k}$ is the number of variables) with $\mathrm{t}$ table of 1,666.

For the Emotional Intelligence variable (X1) obtained tcount> ttable (5.980>1.666) and a significant value $(0.001<0.05)$ means that $\mathrm{Ha}$ is accepted that Emotional Intelligence has a significant effect on improving employee performance.

\section{Analysis of the Effect of Human Relations (X2) on Employee Performance (Y)}

Tabel 1.7

Human Relations Determination Test Result

Model Summary ${ }^{b}$

\begin{tabular}{|l|l|l|r|r|}
\hline Model & $\mathrm{R}$ & R Square & $\begin{array}{c}\text { Adjusted R } \\
\text { Square }\end{array}$ & $\begin{array}{c}\text { Std. Error of } \\
\text { the Estimate }\end{array}$ \\
\hline 1 &, $664^{\mathrm{a}}$ &, 441 &, 430 & 1,89367 \\
\hline
\end{tabular}

a. Predictors: (Constant), HUMAN RELATION

b. Dependent Variable: KINERJA PEGAWAI

\section{Source: Results of SPSS 25 data processing}

Based on the results of the output above, it can explain the summary of the model, which consists of the results of the simple correlation value $\mathrm{R}$ and the coefficient of determination ( $\mathrm{R}$ Square).

1. $\mathrm{R}$ (Pearson correlation) the resulting value is 0.664 , which means that the Human Relations variable (X2) and the employee performance variable (Y) has a strong level of relationship.

2. R Square of 0.441 means the percentage of the contribution of the influence of the Human Relations variable (X2) with the employee performance variable (Y) of 0.441 This means that the percentage level of the influence of Human Relations (X2) with the employee performance variable (Y) is $44.1 \%$ and the rest is influenced by other variables not examined in this study. 


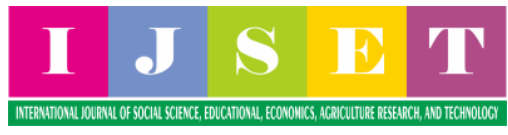

Simple linear regression is used to determine the effect of two or more independent variables with one dependent variable. Following are the results of a simple linear regression:

Tabel 1.8

Hasil Uji Regresi Linier Sederhana Human Relation

Coefficients $^{a}$

\begin{tabular}{|c|c|c|c|c|c|c|}
\hline \multirow[b]{2}{*}{ Model } & & \multicolumn{2}{|c|}{ Unstandardized Coefficients } & $\begin{array}{c}\text { Standardized } \\
\text { Coefficients }\end{array}$ & \multirow[b]{2}{*}{$t$} & \multirow[b]{2}{*}{ Sig. } \\
\hline & & B & Std. Error & Beta & & \\
\hline \multirow[t]{2}{*}{1} & (Constant) & 5,426 & 2,610 & & 2,079 &, 043 \\
\hline & HUMAN RELATION &, 717 & 116 & 664 & 6,160 &, 000 \\
\hline
\end{tabular}

a. Dependent Variable: KINERJA PEGAWAI

\section{Source: Results of SPSS 25 data processing}

$$
Y=a+b x 2=5,426+0,717
$$

The regression equation values above can be explained as follows:

1. The constant value (a) is 5.426 , which means that if the variable (X2) is 0 , then the employee performance variable (Y) gets 5.426.

2. The regression coefficient value for the Human Relation variable (X2) is 0.717 , meaning that if other independent variables are fixed in value and Human Relations (X2) has increased by $1 \%$, then employee performance $(\mathrm{Y})$ will increase by 0.717 . The coefficient is positive, meaning that there is a positive relationship between the work environment and employee performance, the better the level of the work environment, the higher the employee's performance.

The $t$ test is used to test each variable whether it has a significant relationship between the independent variable and the dependent variable. How to determine which variables have a significant relationship are as follows:

1. If tcount $>$ ttable at $\alpha=0.05$ then Ho is rejected or Ha is accepted.

2. If tcount $<$ ttable at $\alpha=0.05$ then Ho is accepted and Ha is rejected.

3. The $t$ distribution table is sought at $\alpha=0.05$ with degrees of freedom (df) $n-k$ or $74-2=72$ ( $\mathrm{n}$ is the number of cases, and $\mathrm{k}$ is the number of variables) with $\mathrm{t}$ table of 1,666.

For the Human Relation variable (X2) obtains tcount> ttable $(6.160>1.678)$ and a significant value $(0.000<0.05)$ means that $\mathrm{Ha}$ is accepted that Human Relations has a significant effect on employee performance.

Analysis of the Effect of Leadership Style (X3) on Employee Performance (Y).

Table 1.9

\section{Leadership Style Determination Test Results}

\begin{tabular}{|l|l|r|r|r|}
\multicolumn{7}{c|}{ Model Summary $^{\text {b }}$} \\
\hline Model & R & R Square & $\begin{array}{c}\text { Adjusted R } \\
\text { Square }\end{array}$ & $\begin{array}{c}\text { Std. Error of } \\
\text { the Estimate }\end{array}$ \\
\hline 1 &, $511^{\text {a }}$ &, 261 &, 246 & 2,17827 \\
\hline
\end{tabular}

a. Predictors: (Constant), GAYA KEPEMIMPINAN

b. Dependent Variable: KINERJA PEGAWAI

Source: Results of SPSS 25 data processing

International Journal of Social Science, Educational, Economics, Agriculture Research, and Technology (IJSET) 
Based on the output results above, it can explain the summary of the model, which consists of the results of the simple correlation value $\mathrm{R}$ and the coefficient of determination (R Square).

1. $\mathrm{R}$ (Pearson correlation) the resulting value of 0.511 means that the leadership style variable (X3) and the employee performance variable (Y) has a strong level of relationship.

2. R Square of 0.261 means that the percentage of the influence of the leadership style variable (X3) with the employee performance variable (Y) is 0.261 . This means that the percentage level of the influence of Leadership Style (X3) with the employee performance variable $(\mathrm{Y})$ is $26.1 \%$ and the rest is influenced by other variables not examined in this study.

Simple linear regression is used to determine the effect of two or more independent variables with one dependent variable. Following are the results of a simple linear regression:

Tabel 1.10

\section{Hasil Uji Regresi Linier Sederhana Gaya Kepemimpinan}

Coefficients $^{\mathrm{a}}$

\begin{tabular}{|c|c|c|c|c|c|c|}
\hline \multirow[b]{2}{*}{ Model } & & \multicolumn{2}{|c|}{ Unstandardized Coefficients } & $\begin{array}{c}\text { Standardized } \\
\text { Coefficients }\end{array}$ & \multirow[b]{2}{*}{$t$} & \multirow[b]{2}{*}{ Sig. } \\
\hline & & $\mathrm{B}$ & Std. Error & Beta & & \\
\hline 1 & (Constant) & 10,025 & 2,785 & & 3,600 &, 001 \\
\hline & GAYA KEPEMIMPINAN &, 532 & 129 & .511 & 4,117 & .000 \\
\hline
\end{tabular}

a. Dependent Variable: KINERJA PEGAWAI

$$
Y=a+b X 3=10.025+0.532
$$

The regression equation values above can be explained as follows:

1. The constant value (a) is 10,025 , meaning that if the Leadership Style variable (X3) is 0 , then the employee performance variable (Y) gets 10,025.

2. The regression coefficient value of the Leadership Style variable (X3) is 0.532, meaning that if other independent variables are fixed in value and the Leadership Style (X3) increases by $1 \%$, then Employee Performance (Y) will increase by $53.2 \%$. The coefficient is positive, meaning that there is a positive relationship between leadership style and employee performance, the better the leadership style, the more employee performance increases.

The $t$ test is used to test each variable whether it has a significant relationship between the independent variable and the dependent variable. How to determine which variables have a significant relationship are as follows:

1. jika $t_{\text {hitung }}>t_{\text {tabel }}$ pada $\alpha=0.05$ maka Ho ditolak atau Ha diterima.

2. jika $t_{\text {hitung }}<t_{\text {tabel }}$ pada $\alpha=0.05$ maka Ho diterima dan Ha ditolak.

3. Tabel distribusi t dicari pada $\alpha=0.05$ dengan derajat kebebasan (df) $n-k$ atau $74-2=72$ (n adalah jumlah kasus, dan $\mathrm{k}$ adalah jumlah variabel) dengan $\mathrm{t}$ tabel sebesar 1.666.

For the Leadership Style variable (X3) obtained tcount> ttable (5.117> 1.666) and a significant value $(0.000<0.05)$ means that $\mathrm{Ha}$ is accepted that leadership style has a significant effect on improving employee performance. 


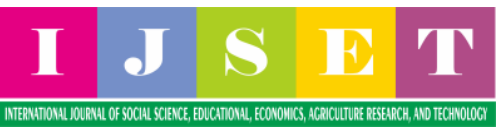

The Effect of Emotional Intelligence (X1), Human Relations (X2), Leadership Style (X3), on Employee Performance (Y)

Tabel 1.11

Independent Variable Determination Test Results on Dependent

Model Summary

\begin{tabular}{|l|l|r|r|r|}
\hline Model & $\mathrm{R}$ & R Square & $\begin{array}{c}\text { Adjusted R } \\
\text { Square }\end{array}$ & $\begin{array}{c}\text { Std. Error of } \\
\text { the Estimate }\end{array}$ \\
\hline 1 &, $739^{\mathrm{a}}$ &, 546 &, 516 & 1,74472 \\
\hline
\end{tabular}

a. Predictors: (Constant), GAYA KEPEMIMPINAN, HUMAN RELATION, KECERDASAN EMOSIONAL

b. Dependent Variable: KINERJA PEGAWAI

\section{Source: Results of SPSS 25 data processing}

Based on the output results above, it can explain the summary of the model, which consists of the results of the simple correlation value $\mathrm{R}$ and the coefficient of determination ( $\mathrm{R}$ Square).

1. $\mathrm{R}$ (Pearson correlation) the resulting value is 0.739 means the correlation between the Emotional Intelligence (X1), Human Relations (X2), Leadership Style (X3) variables, with the Employee Performance (Y) variable has a very strong level of relationship.

2. R Square of 0.546 means that the percentage of the influence of the variable Emotional Intelligence (X1), Human Relations (X2), Leadership Style (X3) with the employee performance variable $(\mathrm{Y})$ is 0.546 . This means that the percentage level of the influence of Emotional Intelligence (X1), Human Relations (X2) and Leadership Style (X3) with the employee performance variable $(\mathrm{Y})$ is $54.6 \%$ and the rest is influenced by other variables not examined in this study.

Tabel 1.12

Results of Multiple Linear Regression Analysis

Coefficients $^{\mathrm{a}}$

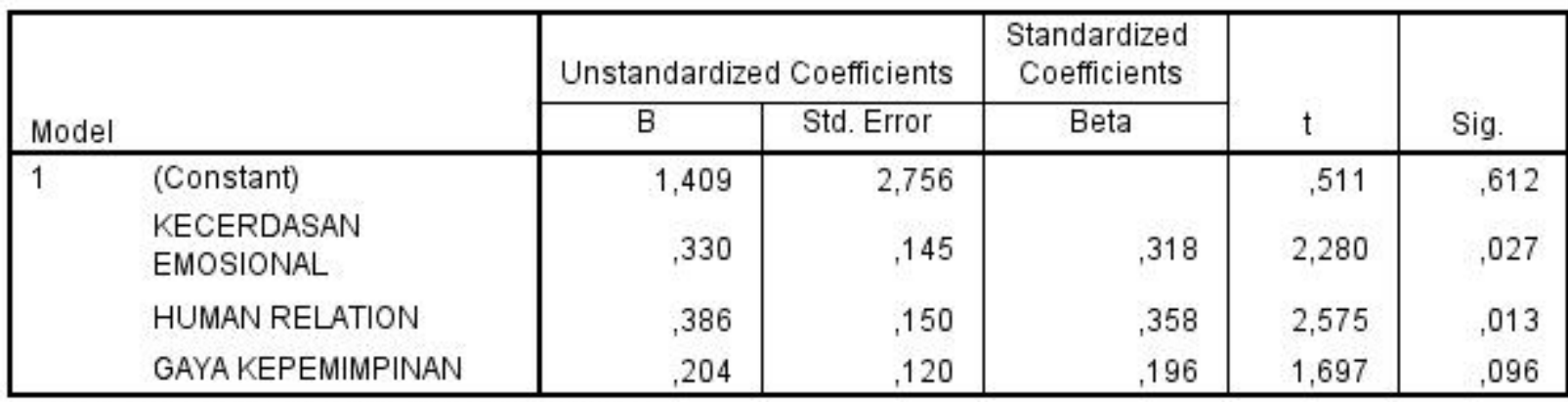

a. Dependent Variable: KINERJA PEGAWAI

\section{Source: Results of SPSS 25 data processing}

In the table above, you can see the constant coefficient $=1.409$ Emotional Intelligence regression coefficient $(\mathrm{b} 1)=0.330$, the Human Relations regression coefficient $(\mathrm{b} 2)=0.386$, the Leadership Style regression coefficient $(b 3)=0.204$. Thus, a multiple linear regression equation can be made as follows:

$$
Y=1.409+0.330 X_{1}+0.386 X_{2}+0.204 X_{3}
$$


The regression equation values above can be explained as follows;

1. A constant of 1.409, meaning that if the variable Emotional Intelligence (X1), Human Relations (X2), Leadership Style (X3), with the employee performance variable (Y) the value is 1.409 .

2. The regression coefficient for the Emotional Intelligence variable (X1) is 0.330, meaning that if the other independent variables are fixed in value and the Emotional Intelligence (X1) has increased by $1 \%$, then employee performance (Y) will increase by $33 \%$. The coefficient is positive, meaning that there is a positive relationship between emotional intelligence and employee performance, the higher the emotional intelligence, the higher the employee's performance.

3. The regression coefficient for the Human Relations variable (X2) is 0.386 , meaning that if other independent variables are fixed in value and Human Relations (X2) has increased by $1 \%$, then the employee's performance (Y) will increase by $38.6 \%$. The coefficient is positive, meaning that there is a positive relationship between Human Relations and employee performance, the better the level of Human Relations, the greater the employee's performance.

4. The regression coefficient of the Leadership Style variable (X3) is 0.204, meaning that if other independent variables have a fixed value and the Leadership Style (X3) has increased by $1 \%$, then the employee's performance (Y) will increase by $20.4 \%$. The coefficient is positive, meaning that there is a positive relationship between leadership style and employee performance, the better the existing leadership style, the more employee performance increases.

How to determine which variables have a significant relationship are as follows:

1. If tcount $>$ ttable at $\alpha=0.05$ then Ho is rejected or Ha is accepted.

2. If tcount $<$ ttable at $\alpha=0.05$ then Ho is accepted and Ha is rejected.

3. The $t$ distribution table is sought at $\alpha=0.05$ with degrees of freedom (df) $n-k$ or $74-2=72$ ( $\mathrm{n}$ is the number of cases, and $\mathrm{k}$ is the number of variables) with $\mathrm{t}$ table of 1,666.

\section{CONCLUSION}

Based on the research and discussion that has been described above, the following will conclude a number of things regarding this research:

1. Based on the results of the $t$ test, the Emotional Intelligence variable (X1) obtained tcount> ttable $(5.980>1.666)$ and a significant value $(0.001<0.05)$, meaning that $\mathrm{Ha}$ is accepted that Emotional Intelligence has a significant effect on employee performance.

2. Based on the results of the t test, the Human Relations variable (X2) obtained tcount> ttable $(6.160>1.678)$ and a significant value $(0.000<0.05)$ means that $\mathrm{Ha}$ is accepted that Human Relation has a significant effect on employee performance.

3. Based on the results of the t test, the variable Leadership Style (X3) obtained tcount $>$ ttable (5.117> 1.666) and a significant value $(0.000<0.05)$ means that $\mathrm{Ha}$ is accepted that Leadership Style has a significant effect on improving employee performance.

4. That the Emotional Intelligence, Human Relations and Leadership Style variables have a significant effect on employee performance at the Loka Rehabilitasi BNN Batam. 


\section{REFERENCES}

Gerson, RF (2004). Measuring Customer Satisfaction . Jakarta: PPM.

Haefner, JE, Deli-Gray, Z., \& Rosenbloom, A. (2011), "The importance of brand liking and brand trust in consumer decision making: Insights from Bulgarian and Hungarian consumers during the global economic crisis", Managing Global Transitions : International Research Journal, Vol. 9 No.3, pp.249-273.

Hafeez, S., \& Hasnu, S. (2010), "Customer satisfaction for cellular phone in Pakistan: A case study of Mobilink", Business and Economics Research Journal, Vol.1 No.(3), pp. 35-44.

Hafeez, S. and Muhammad, B. (2012), "The Impact of Service Quality, Customer Satisfaction and Loyalty Programs on Customer's Loyalty: Evidence from Banking Sector of Pakistan", International Journal of Business and Social Science, Vol.3 No. 16, pp. 200-209.

Heriyadi, Listiana, E. and Lay, YN (2018). An Analysis of the Influence of Service Quality, Personal Selling and Complaint Handling and Trust on Customer Retention (Survey of Bank Harda International Savings Customers, Pontianak Branch). Volume 7 Number 2.

Ilham, R. N., Erlina, K. A. F., Silalahi, A. S., Saputra, J., \& Albra, W. (2019). Investigation of the bitcoin effects on the country revenues via virtual tax transactions for purchasing management. Int. J Sup. Chain. Mgt Vol, 8(6), 737.

Ilham, R. N., Sinaga, S., Putri, D. E., Sinta, I., \& Fuadi, F. (2021). EFEK DARI LEVERAGE DAN UKURAN PERUSAHAAN DALAM MEMENGARUHI TINGKAT PROFITABILITAS. JURNAL ILMIAH EDUNOMIKA, 5(02).

Khaddafi, M., Subrata, H., Apriyanto, E., Iqbal, M., \& Darmawan, W. (2022). PENGENALAN DASAR PENGOPERASIAN KOMPUTER PADA ANAK USIA DINI. JATIMIKA: Jurnal Kreativitas Mahasiswa Informatika, 2(3).

Kotler.P. (2008). Marketing Principles 2. Twelfth Edition. Jakarta : Erlangga.

Lasta Irawan, A., Multazam, M. ., Nur Ilham, R. ., \& Kayacilar, C. . (2021). INFLUENCE OF PRODUCT QUALITY ON CONSUMER PURCHASE INTEREST WITH CUSTOMER SATISFACTION AS A VARIABLE INTERVENING IN BLACK ONLINE STORE MARKET LHOKSUMAWE CITY: (Case Study on Black Market Online Store Customers in Lhoksumawe City). International Journal of Social Science, Educational, Economics, Agriculture Research, and Technology (IJSET), 1(1), 1-10. https://doi.org/10.54443/ijset.v1i1.1

Noor, H., \& Riinawati, R. (2021). IMPROVING MANAGEMENT OF EARLY CHILDHOOD EDUCATION (PAUD) THROUGH IDENTIFICATION OF INSTITUTIONAL PROBLEMS. Berajah Journal, 1(3), 117-124.

Riinawati, R. (2021). The Development of Information Technology and Its Influence on the Field of Management Accounting. Journal of Financial and Tax, 1(2), 131-149. 
THE EFFECT OF EMOTIONAL INTELLIGENCE, HUMAN RELATION AND LEADERSHIP STYLES ON EMPLOYEE PERFORMANCE AT THE LOKA REHABILITATION BNN BATAM DOI: https://doi.org/10.54443/ijset.v1i2.10 